\title{
Experimental Study on the Mechanics Character of Lava in the Area of Xujiaweizi
}

\author{
Xu Zhang \& Yinghu Zhai \\ MOE Key Laboratory of Petroleum Engineering, China University of Petroleum \\ Beijing 102249, China \\ E-mail: zhangxu_wuhan@yeah.net
}

The research is financed by the Science and Technology Project of "Study on the Deep Stratum Character Evaluation and Bit Evaluation Method and Model Selection" of Daqing Oil Field Ltd. Co. of China National Petroleum Corporation (No. 20071100014586). (Sponsoring information)

\begin{abstract}
The Xujiaweizi rift in the north of Songliao Basin is the largest volcanic gas reservoir in China, and because the mechanics character of lava largely influences the production and development of the oil field, so it is necessary to make clear the mechanics character of laves in this area. After analyzing the lava lithology of the Daqing Xujiaweizi, taking the rock mechanics and the elastic mechanics as the theoretical base, six kinds of representative lava mechanics characters in this area are tested in the laboratory, and relative basic mechanics parameters are obtained, which can exert important function for relative engineering design. The test results show that the lavas in this area are representative brittle rocks and the rock fracture mainly is brittle failure, and with the increases of the burial depth and the confining pressure, the rocks present character of plastic failure. The research results will play a very important role in the volcanic gas reservoir exploitation in Daqing Xujiayanzi.
\end{abstract}

Keywords: Rock mechanics, Lithology, Lava, Experimental study

\section{Introduction}

With the developments of the petroleum industry and the oil-gas field exploration, large numerous of lava oil-gas reservoirs have been found and the oil-gas flows with commercial values have been obtained in China. The Xujiaweizi rift in the north of Songliao Basin is the largest volcanic gas reservoir in China, and the proved reserves have achieved above hundred billions cubic meters (He, 2008, P.463-471). The exploring practice shows that the lava-buried depth of this area generally is $3000 \mathrm{~m}-5500 \mathrm{~m}$, and the north of the rift mainly includes intermediate-basic rocks (andesites, basalt-andesites) and the south of the rift mainly includes intermediate acid rocks and acid rocks (dacistes and rhyolites). Because of the differences of the stratum lithology, the mechanics characters of stratum rocks are different, which will influence the exploration and development of the oil field. Therefore, it is necessary to systematically study the mechanics characters of lava stratum. The relative research can not only offer powerful technical support to enhance the drilling speed of well for Daqing Oilfield, but have very applicable values for the lava stratum drilling in other oilfields.

\section{Analysis of stratum lithology}

The lavas in the Xujiaweizi rift belong to the volcanic association from the Late Jurassic Epoch to the Early Cretaceous Epoch $\left(J_{3}-K_{1}\right)$. And the lavas are on the base of unconformity permo-carboniferous system $(C-P)$ opimetamorphic rock series, and are covered by the Mesozoic Era Cretaceous ( $\left.K_{1}\right)$ Denglouku group $\left(K_{1} d\right)$ and Quantou group $\left(K_{1} q\right)$ sedimentary rocks. According to the actual situation of the deep lava stratum in Xujiaweizi, and the principle of "if the characters of measured wells are similar, the geological meanings are same (Ran, 1996)", the lavas in this area can be divided into six representative rock types, i.e. basalt, andesite, dacite, rhyolite, tuff and breccia (seen in Figure 1).

\section{Experimental study of lava mechanics characters}

The experiment is the base of all scientific researches. To measure the basic mechanics characters of lava by certain 
testing method and measures is one of main contents of the lava mechanics study. The experiment research of the rock mechanics characters includes two aspects (Lou, 2006, P.94-104), i.e. the distortion character of rocks, and the intention character of rocks. The experiment research of rock distortion means to study the distortion rules of the rock sample under various loads, such as the elastic distortion, the plastic distortion, the viscidity flow and the failure rule, and it reflects the mechanics attribute of rocks. The experiment research of intention character is to study the relationship between the maximum stress (limit of intension) and the relationship between the stress and the fracture of the rock sample, and it reflects the ability to resist the fractures and the fracture rules of rocks.

\subsection{Experiment equipments}

(1) TZ-1 rock core catcher (the drilled rock core: $\Phi=25 \mathrm{~mm}, \mathrm{~L}=80 \mathrm{~mm}$ ).

(2) Three-axis rock testing system (MTS-816 Testing System). Take the rock core $(\Phi=25 \mathrm{~mm}, \mathrm{~L}=50 \mathrm{~mm})$, and put the plastic enveloped rock core in the confining pressure room, and nip the strain gauge, and hood the confining pressure box, and exert axial load until the rock core is destroyed and record the failure pressure. The stress of rock failure is the pressive strength of the rock.

(3) Multi-functional rock drillability tester made by the Instrument Factor of China University of Petroleum (East China) (the drilling pressure: $890 \pm 20 \mathrm{~N}$, rev: $55 \pm 1(\mathrm{r} / \mathrm{min})$, pre-drilling depth: $0.2 \mathrm{~mm}$, work drilling depth: $2.4 \mathrm{~mm}$, displacement differentiation: $0.01 \mathrm{~m}$, timing precision: $0.01 \mathrm{~s}$ ).

(4) Rock rigidity tester made by the Instrument Factor of China University of Petroleum (East China) (the diameter of bit: $2 \mathrm{~mm}$, the axial pressure: $0-5000 \mathrm{~kg}$, the displacement range: $0-10 \mathrm{~mm}$ ).

\subsection{Testing of rock mechanics parameters (Yang, 2001, P.55-58)}

(1) Single-axis pressive strength $\sigma_{c}$ :

$$
\sigma_{c}=P / A
$$

Where, $P(\mathrm{~N})$ is the failure load of rock sample and $A\left(\mathrm{~mm}^{2}\right)$ is the original transect area of the sample.

(2) Elastic modules E: it can be obtained by the stress-strain curve in the condensation experiment of the standard rock sample, i.e.

$$
E=\frac{\Delta \sigma_{z}}{\Delta \varepsilon_{z}}
$$

Where, $\Delta \sigma_{z}(\mathrm{MPa})$ is the increment of axial stress and $\Delta \varepsilon_{z}(\mathrm{~m})$ is the increment of strain.

(3) Poisson ratio $\mu$ : it is the ratio of the transverse relative condensation and the lengthways relative stretch, i.e.

$$
\mu=\frac{\Delta d / d}{\Delta L / L}
$$

Where, $\mathrm{L}$ and $\Delta \mathrm{L}(\mathrm{m})$ respectively are the rock length and the lengthways relative stretch, $\mathrm{d}$ and $\Delta \mathrm{d}$ respectively are the rock diameter and the transverse relative condensation.

(4) Drillability $K_{d}$ : it is related with the time needed to drill into the regulated depth of the measured rock $T$ (s), i.e.

$$
K_{d}=\log _{2} T
$$

(5) Rigidity $K_{h}$ : it is the load on unit area of the contact face when the brittle failure happens, i.e.

$$
K_{h}=P / S
$$

Where, $P(\mathrm{~N})$ is the axial load, and $S\left(\mathrm{~mm}^{2}\right)$ is the bottom area of the bit.

\subsection{Experiment results and discussions}

Thirteen representative rock cores in Daqing Xujiaweizi are selected as the research object in the article, and their mechanics parameters are tested in the labotory one by one (seen in Figure 1). Figure 2 is part of the stress-strain curve of rock core.

From Table 1 and corresponding core stress-strain curves, the texture of lavas in this area is hard, and the drillability is bad, and the grinding character is strong, and the pressive strength is not even, and these lavas belong to representative brittle rocks, and the fracture mainly is brittle failure. For the rhyolites, the drillability value is above class 9, the stratum rigidity is in $3000 \mathrm{MPa}-5000 \mathrm{MPa}$, and the pressive strength is in $110-150 \mathrm{MPa}$, which indicates that the rocks are hard and dense, and the drillability is bad. For the tuffs, the drillability value is in class 6-class 10, the stratum rigidity is in $2000 \mathrm{MPa}-2800 \mathrm{MPa}$, and the pressive strength is in $80-120 \mathrm{MPa}$, which indicates that the rigidity of the rocks is high, the rocks are hard and dense, and the drillability is bad. For the andesites, the drillability value is in class 7.0-class 8.5 , the stratum rigidity is in $2500 \mathrm{MPa}-4000 \mathrm{MPa}$, and the pressive strength is in $80-130 \mathrm{MPa}$, which indicates that the 
rigidity of the rocks is high, the drillability is bad, and the passive strength is not even. For the breccias, the drillability value is in class 5.8 -class 6.5 , the stratum rigidity is in $1300 \mathrm{MPa}-2000 \mathrm{MPa}$, and the pressive strength is in $65-80 \mathrm{MPa}$, which indicates that the rigidity of the rocks is high, and the passive strength is not even. For the basalts, the drillability value is about class 9 , the stratum rigidity is in $4000 \mathrm{MPa}-4300 \mathrm{MPa}$, and the pressive strength is about $110 \mathrm{MPa}$, which indicates that the drillability of the rocks is bad and the lithology is hard and dense. For the dacites, the drillability value is about class 8.7 , the stratum rigidity is above $3000 \mathrm{MPa}$, and the pressive strength is about $100 \mathrm{MPa}$, which indicates that the drillability of the rocks is bad and the the rigidity is high. Therefore, when designing the lava reservoir waterpower fracture and selecting bit model, these differences should be fully considered to design reasonable construction parameters and effectively enhance the rev of mechanical drill. In addition, from the fracture surface of experimental sample, most lava presents the characters of brittle failure and cutting failure. And with the increases of the depth and the confining pressure, the plastic failures occur, which could offer important references to analyze the fracture waterpower crack formation and the natural crack formation of the oil field.

\section{Conclusions}

(1) The lithology of lavas in this area is complex, the texture is hard, the drillability is bad, the grinding character is obvious and the pressive strength is not even, and the lavas belong to representative brittle rocks.

(2) The fracture of lavas mainly is brittle failure, and with the increases of depth and confining pressure, the plastic failure occurs, this character could offer important references to analyze the waterpower fracture crack formation and the natural crack formation of the oil field.

\section{References}

He, Dian, Li, Jianghai \& Liu, Shoujie et al. (2008). Discovery of a giant caldera in the Yingcheng Formation in the Xujiaweizi fault depression, northern Songliao Basin. Geology in China. No. 35(3). P. 463-471.

Lou, Yishan \& Jin, Yequan. (2006). Rock Mechanics and Oil Engineering. Beijing: Petroleum Industry Press. P. 94-104. Ran, Qiquan. (1996). Reservoir Characterization of Fractured Volcanic Gas Reservoir in Deep Zone. SPE 104441.

Yang, Guitong. (2001). Elastic Mechanics. Beijing: Higher Education Press. P. 55-58. 
Table 1. Room rock mechanics parameter testing results of Daqing Xujiaweizi

\begin{tabular}{|c|c|c|c|c|c|c|c|c|c|c|}
\hline $\mid \begin{array}{c}\text { No. of } \\
\text { Core }\end{array}$ & $\begin{array}{c}\text { No. of } \\
\text { Well }\end{array}$ & Depth $(\mathrm{m}$ & Lithology & $\begin{array}{l}\text { Quality } \\
\left(\mathrm{g} / \mathrm{cm}^{-3}\right)\end{array}$ & $\begin{array}{l}\text { Modulus } \\
\text { of } \\
\text { elasticity } \\
(\mathrm{GPa})\end{array}$ & $\begin{array}{c}\text { Poisson } \\
\text { ratio }\end{array}$ & $\mid \begin{array}{c}\text { Max. of } \\
\text { drillabil } \\
\text { ity }\end{array}$ & $\begin{array}{l}\text { Rigidity } \\
\text { (Mpa) }\end{array}$ & $\begin{array}{c}\text { Pressive } \\
\text { strength } \\
\text { (Mpa) }\end{array}$ & $\begin{array}{l}\text { Rock } \\
\text { fracture }\end{array}$ \\
\hline 1 & SS 2 & 3005.20 & $\begin{array}{l}\text { Offwhite } \\
\text { rhyolite }\end{array}$ & 13.2 & 11.5 & 0.14 & 9.12 & 4779.10 & 128.9 & $\begin{array}{l}\text { Brittle } \\
\text { failure }\end{array}$ \\
\hline 2 & SS 2 & 3279.36 & $\begin{array}{c}\text { Green-gray } \\
\text { tuff }\end{array}$ & 11 & 10.4 & 0.22 & 7.51 & 2220.63 & 89.4 & $\begin{array}{l}\text { Cutting } \\
\text { failure }\end{array}$ \\
\hline 3 & DS 1 & 3320.54 & $\begin{array}{l}\text { Celadon } \\
\text { rhyolite }\end{array}$ & 17.9 & 16.3 & 0.34 & $>10$ & 5093.27 & 134 & $\begin{array}{l}\text { Brittle } \\
\text { failure }\end{array}$ \\
\hline 4 & DS 1 & 3501.36 & Andesite & 15 & 9.9 & 0.05 & 8.11 & 2879.97 & 97 & $\begin{array}{l}\text { Brittle } \\
\text { failure }\end{array}$ \\
\hline 5 & DS 1 & 3771.00 & $\begin{array}{c}\text { Rhyolite-daci } \\
\text { te }\end{array}$ & 14.3 & 10.4 & 0.24 & 8.78 & 3748.10 & 112.7 & $\begin{array}{l}\text { Brittle } \\
\text { failure }\end{array}$ \\
\hline 6 & SS 5 & 3878.64 & Gray tuff & 10 & 7.5 & 0.11 & 6.4 & 2342.99 & 78.3 & $\begin{array}{l}\text { Cutting } \\
\text { failure }\end{array}$ \\
\hline 7 & SS 5 & 3981.54 & Gray tuff & 11.1 & 8 & 0.26 & 6.65 & 2000.25 & 80.2 & $\begin{array}{l}\text { Brittle } \\
\text { failure }\end{array}$ \\
\hline 8 & XS 3 & 4324.39 & Tuff-breccia & 9.9 & 6.3 & 0.17 & 6.86 & 2002.60 & 74.3 & $\begin{array}{l}\text { Plastic } \\
\text { failure }\end{array}$ \\
\hline 9 & So-S 1 & 4811.01 & Andesite & 17 & 7.2 & 0.26 & 7.3 & 2801.30 & 86.5 & $\begin{array}{l}\text { Brittle } \\
\text { failure }\end{array}$ \\
\hline 10 & So-S 1 & 4980.70 & $\begin{array}{l}\text { Volcano } \\
\text { breccia }\end{array}$ & 10.8 & 5.9 & 0.09 & 5.82 & 1512.44 & 65.3 & $\begin{array}{l}\text { Plastic } \\
\text { failure }\end{array}$ \\
\hline 11 & So-S 1 & 5201.72 & $\begin{array}{c}\text { Andesite-bas } \\
\text { alt }\end{array}$ & 13 & 9.3 & 0.23 & 8.93 & 3790.01 & 115.2 & $\begin{array}{l}\text { Brittle } \\
\text { failure }\end{array}$ \\
\hline 12 & PS 1 & 5280.30 & $\begin{array}{l}\text { Amaranth } \\
\text { andesite }\end{array}$ & 13.4 & 8 & 0.21 & 8.38 & 3963.20 & 113.3 & $\begin{array}{l}\text { Brittle } \\
\text { failure }\end{array}$ \\
\hline 13 & PS 1 & 5343.65 & Tuff & 11.9 & 7.4 & 0.3 & 7.2 & 2713.70 & 97.3 & $\begin{array}{l}\text { Plastic } \\
\text { failure }\end{array}$ \\
\hline
\end{tabular}




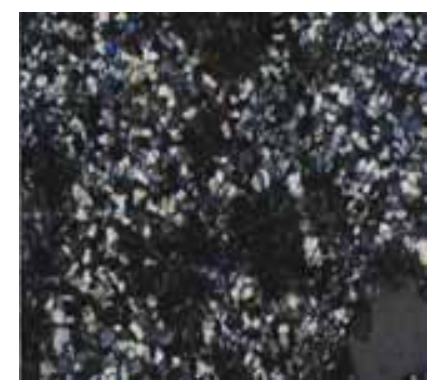

SS 6 Rhyolite (orthogonal) $3508.38 \mathrm{~m}$

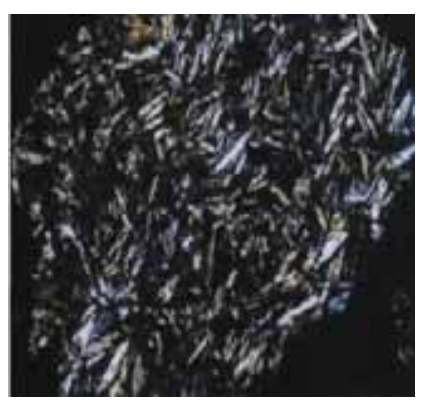

XS 4 Andesite (orthogonal) $4258.4 \mathrm{~m}$

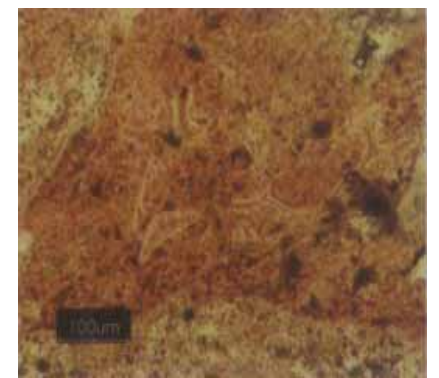

XS 6 Tuff (single-deflection) $3615.41 \mathrm{~m}$

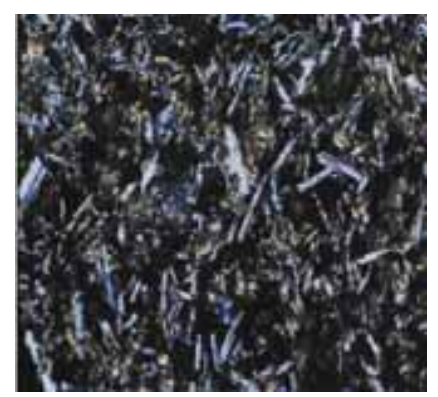

XS 1 Basalt (orthogonal) $3779.4 \mathrm{~m}$

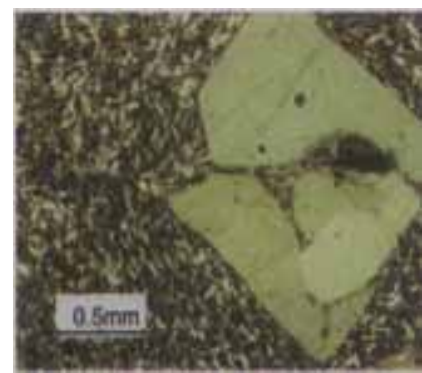

XS 5 Dacite (orthogonal) $4051.52 \mathrm{~m}$

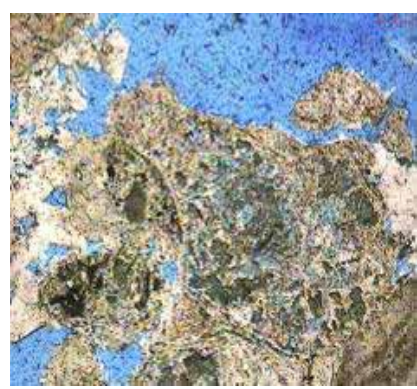

XS 8 Volcano breccia (single-deflection) 3761.2m

Figure 1. Representative Lava Lithology Characters of Xujiaweizi
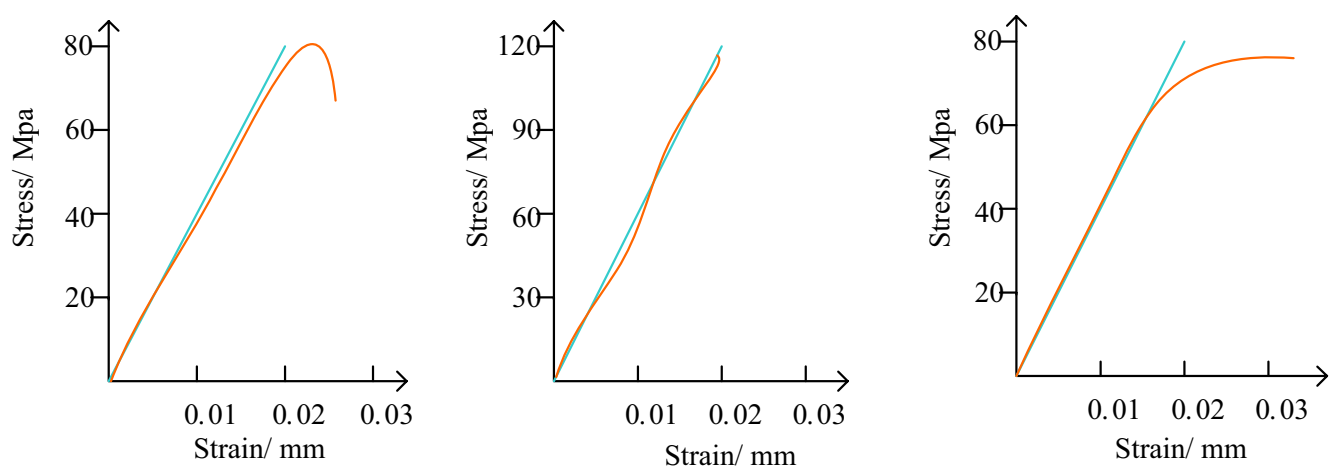

Stress- Strain Curve of Rock Core 7 Stress- Strain Curve of Rock Core 11 Stress- Strain Curve of Rock Core 8

Figure 2. Stress-strain Curve of Rock Core 